\title{
ONTOLOGY OF SCIENTIFIC COGNITION OF SHADOW ECONOMY AND ECONOMIC SHADING
}

\author{
Pavlo Pashko', Olga Tylchyk ${ }^{2}$ \\ University of the State Fiscal Service of Ukraine, Ukraine \\ Oleksandr Kotukha ${ }^{3}$ \\ Lviv Trade and Economic University, Ukraine
}

\begin{abstract}
The purpose of this article is to characterize deformation problems of the domestic economy, particularly the influence of negative factors on it, resulting in its shading. This article analyses the approaches to statement that the shadow economy is one of the major global risks of the coming decade. The context of legal regulation is directly related to form an effective system of ensuring of Ukraine's national security is possible under the condition of thorough development of the areas of counteraction to individual threats in the relevant spheres, including the economy. At the same time, a special attention is paid to the view that the economic shading although is officially recognized as a threat to national security, however, the notion that should denote this phenomenon and be a basic one is not formulated in any current normative legal act. The formation of the concepts of "shadow economy" and "economic shading" in the interconnection is a logical stage of cognitive activity within both the economic and legal sciences. The practical significance of the results of scientific research is the formation of the hypothesis, the essence of which is the new knowledge about the shadowing of the economy as a legal category on the basis of systemdefined signs, causes and of dialectical connection of the phenomenon of the shadow economy and the process of dynamic transformation. A given hypothesis is intended to change the strategic directions and guidelines in the formation of economic policy to neutralize harmful processes of shading of the legal sectors of the economy. The value of the results obtained of the current research is due to the transnational nature of the phenomenon of the shadow economy and connection of such a phenomenon with other harmful processes that are produced within the economic space and lead to the institutionalization of the global economic crisis. Methodology. A methodological framework of the economic security research is defined by complex of scientific cognition methods that allow us to look at this problem as a multi-aspect, interdisciplinary phenomenon. On the basis of the system-based, structural, systemic-functional, and other scientific approaches, the idea of the economic security has formed a complex systemic category covering the theoretical and practical level of economic activity.
\end{abstract}

Key words: shadowing of the economy, shadow economy, administrative and legal provision, administrative and legal measures, prevention of corruption, offenses in economic sphere, counteraction of shadowing of economy, money laundering of proceeds from crime.

JEL Classification: H2O, H30, K23

\section{Introduction}

Deformation problems of the domestic economy, particularly the influence of negative factors on it, resulting in its shading, now are widely discussed both in the scientific community, speeches of the politicians and at the household level. It is caused, in particular, by the statement that the shadow economy is one of the major global risks of the coming decade. Today, the shadow economy in Ukraine reached a critical level, and are about 50 percent of gross domestic product (hereinafter - GDP), moreover, the greatest attention in recent years has been paid to its increasing caused by a due complication of the political and economic situation in Ukraine. Moreover, it is impossible to estimate the mass (level, volumes etc.) of the shadow economy, because the fluctuations in determining the

\footnotetext{
Corresponding author:

${ }^{1}$ University of the State Fiscal Service of Ukraine.

E-mail: papavl@ukr.net

${ }^{2}$ University of the State Fiscal Service of Ukraine.

E-mail: o.v.tilchik@ukr.net

${ }^{3}$ Department of Civil Law and Process, Lviv Trade and Economic University.

E-mail: kotuha1@ukr.net
} 
ratio of the shadow economy to GDP are from 15 to 70 percent. It can hardly be considered as satisfactory, which indicates the need to continue the scientific research for the results formation that will provide the practical needs.

The higher mentioned determines the active development of research, the subject of which are the regularities and determinants for the formation of the economy shadowing, the methods of its calculation, the impact on various economic institutions, in particular, on national security in the field of economy and finance. Economic security in the broad sense is a national program for the development of productive forces and industrial relations, which takes into account the interests of all social groups and involves their participation in its implementation. In the narrow sense, it is a number of methods and means of counteracting the negative manifestations of market forces, which are manifested as a result of unorganized participation in world economic processes. Thus, the mechanism of economic security providing consists of two blocks: the first one is the protection of national interests from the factors of negative influence (protection), and the second one is the realization of economic interests (Tsishkovskiy, Strelnikov, 2007). The essence of economic security is manifested and specified through the system of its partial forms - the system of economic security providing, which more or less has an economic component (Muntian, 1999).

To form an effective system of ensuring of Ukraine's national security is possible under the condition of thorough development of the areas of counteraction to individual threats in the relevant spheres, including the economy.

\section{Economic shading as a category of the security system of Ukraine}

In view of the noted above, it is worthwhile to start with the thesis that security is an element of the legal system, where society and the state are its objects, and the economy, as the economic activity of society, is a system of economic relations, which is directly concerned to the important spheres of social life, connected to production, distribution, exchange, and consumption of material goods, aimed to meet human needs. Interacting with all spheres of social relations in public life, the economy is socialized and becomes a part of the social life of a person (Kochev V.A., 2010). By its political and economic base, it penetrates into the public sphere of life and, therefore, acquires legal form, aimed at influencing stately on the economy in general and in the interests of man and society to following approach by Hermann Hoppe (1995), but the legal "foundation in the form of property rights and supremacy of the law" is the necessary condition for its successful functioning (North, 2010). Thus, economics, security and law are interrelated, because a society is their family (Skakun, 2013).

Thus, the research of the phenomenon of economic shading as a threat to Ukraine's national security should be carried out in a plane where the achievements in economy, sociology, law, and science of secure are combined, and the concepts and theories made by the scientists should not produce discrepancies and inconsistency of approaches to the affected scientific issues since this threatens unproductive duplication of research and, accordingly, ineffective use of scientific potential and financial resources (Popovych, 2001).

In view of the abovementioned, it should be noted that the economic shading although is officially recognized as a threat to national security, however, the notion that should denote this phenomenon and be a basic one is not formulated in any current normative legal act.

Appeal to the research of national economists, lawyers, and sociologists made it possible to establish that, instead of the term "economic shading", the term "shadow economy" is used. The same, in essence, "substitution" is also observed in the provisions of individual legal acts. Thus, in the Law of Ukraine "On Fundamentals of National Security of Ukraine” (2003), "shadowing" of the national economy is among the threats of national security in the economic sphere. The Methodological Recommendations on Calculating the Level of Economic Security of Ukraine (approved by the Decree of the Ministry of Economic Development and Trade of Ukraine dated October 29, 2013 No. 1277) (2013) indicate the existence of such an indicator of the level of macroeconomic security as the level of "economic shading" and indicates that it is calculated accordingly to the Methodological Recommendations for Calculating the Level of the Shadow Economy (Order of the Ministry of Economy dated February 18, 2009 No. 123). The higher mention allows suggesting that the authors of this document identify the following two concepts. Obviously, there is a substitution of terms, which are called different in content or one-way, generic phenomena - the shadow economy and the economic shading. It is clear that in these circumstances, research concerning their differentiation and correlation became more actual and there is a necessity to refer to the scholars' research on the problems of the shadow economy to actualize the "economic shadowing" as an object of scientific research and the formation of appropriate principles for counteracting the spread of this threat.

\section{Shadow economy and economic shadowing: the definition of the essence of phenomena}

Describing any phenomenon, we can say that it is worth firstly to address the lexical meaning of the constituent concepts that make it. The notion of "economy" (from the Greek oíkosvonos - literally is the art of household 
management) can mean the following: the science of using a variety of limited resources, as well as production, marketing, distribution, consumption of goods and services; economy (household management), sphere of human economic activity, in which the life benefits are created, distributed and consumed.

The adjective "shadow", according to its lexical meaning, characterizes the economy as a part of the whole phenomenon (economy), closed from the implementation of the organization and management by the authorized entities. The above-mentioned phrase "shadow economy" is the most widespread, but there are other terms used to describe this phenomenon in the scientists research and are used as synonyms: "informal economy", "black economy", "grey economy", "illegal economy", "informal economy", "secret economy", "unregistered economy" etc. This situation is connected both with the international nature of the phenomenon and with its correlation in accordance with the field of knowledge (the characteristic of the described phenomenon as interbranch one), within which it is applied and investigated.

National scientists do not always distinguish between the shadow economy and the economic shadowing. Even mentioning the system of institutional threats to economic security, Z.S. Varnaliy speaks about the "shadow economy", although in the text of the Law of Ukraine, and indeed in the publication the scientist individually defines the shadow economy, indicating that it is a key form of the institutional threats system and it is the economic activity of business entities, which is not taken into account, is not controlled, and is not taxed by the state and/or is aimed at receiving income through violation of the current legislation. However, it continues to speak about the systemic consequences of economic shadowing in Ukraine, which are the losses of the effectiveness of monetary and credit policy levers due to the high volumes of UAH and foreign exchange mass turnover etc. (Varnalia, 2015; Varnalia, 2017).

Speaking about the negative consequences of the manifestation of this or that phenomenon, foremost, it is necessary to establish its mutuality and interdependence with other phenomena. Accordingly, it is possible to trace on the integral approach to determining the mass of so-called "shadow" income, since the authors of the above conclusions take on the function of the shadow economy, which is mediated by negative consequences for the economy as a whole for the basis. Applying the above formula, it is possible to establish that "shadow income", mediated by the negative factors of its existence, is equal to the amount of damage caused to the so-called "legal economy", which is the initial (primary) point for the development of the listed consequences in the social sphere. In this approach, an attention is focused on damage to the state, and not to the general national interests, whose correlation (damage to the state and to the national interests) can get somewhat opposite result, since, having received income, any person satisfies his (private) interest, the latter does not always become the object of counteraction, in some cases, it is even the object of protection (defence) (Varnalia, 2015; Varnalia, 2017).

This is confirmed by the thesis, according to which the "shadow economy" is endowed with a "positive function" and is mediated by the approach to the necessity of determining the limits of state intervention in the economy as a whole. Swiss economist D. Cassel has identified three positive functions that perform the shadow economy in a market economy as follows:

1) the function of "economic ink";

2) the function of "social shock absorber", which allows mitigating unwanted social contradictions in society between different segments of the population, since informal employment facilitates the material state of the poorly-formed groups;

3) the function of the "built-in stabilizer", since its resources are gradually moving to the legal economy (Matzievsky, 2010).

Such an approach, while transposing its provisions into domestic scientific research, leads to certain inconsistencies, since it raises a remark about the possibility of combining the indicated positive function of the "shadow economy" with the content of this phenomenon, which is considered as an antipode to the economy, which is carried out in the legal field. In other words, it is made the assumption about the positive impact of the offenses on the social and economic development of society; therefore, it is not possible to establish the dialectical interconnection between the positive reasons for the aim of "shadow economy" with its negative consequences. It should be noted that the actual "shadow economy" is not recognized as a threat to the national interests, as opposed to "shadowing". However, characterizing the latter one, it is often indicated on an increase in the mass of the shadow economy, simultaneously it determines as critical one when its correlation to the economy has reached the 30 per cent barrier. This correlation certifies the strengthening of its negative, destructive impact on the economic system. Therefore, an increase in the mass of the shadow economy above the permissible value, obviously, as a result of shadowing, is an indicator of the threat in this case.

The content of the threat is directly related to its form, under which the ways of external expression of the threat are understood. The form provides the content of the threat a factual certainty in the objective world, which determines its boundaries. Due to the form, the threat becomes available for research and evaluation (Varnalia, 2009).

In support of this, it is worth to point out the indisputable of the fact that the large volumes of the shadow economy are a factor of deepening of imbalances existing in the economy, while remaining one of the 
greatest challenges to the state economic security, the trends of change will continue to determine scenarios of the state economic development in whole, as they are characterized by a stable reciprocal dependence between the indicators of economic levels security and shadow economy (Report on conducting a national risk assessment in the field of prevention and counteraction to the legalization (laundering) of proceeds from crime and terrorist financing 2016).

\section{The main approaches to the content of the phenomenon called "shadow economy"}

Attempts to single out the obligatory components of the shadow economy and their signs are made in the legal encyclopaedia, edited by Y.S. Shemshuchenko, which states that the shadow economy can be defined as economic processes (production, distribution, exchange, consumption of the goods and services), which are hidden by their participants from the control of the state and society, are not fixed by state statistics, and the material results of these processes do not fall to the National Gross Domestic Product (Shemshuchenko, 2002). That is, the authors emphasize the importance of allocating two basic components that characterize the shadow economy - they are the following: economic processes and their material results. The features of the economic processes that allow enlisting them to the shadow ones, according to the scientists, are the fact of concealment of the economic processes from the control of state and society. At the same time, the authors do not focus on specifying the way of such concealment (legal or illegal), even it is not indicated, and a sign of concealment is a way or a condition that characterizes the activity. The second sign of economic activity is that it is not fixed by state statistics. Moreover, again, the reasons for the absence of such fixation are not specified.

The development of a unified approach to the problem of the shadow economy was carried out by a group of experts from national and international statistical organizations. The result of this work was a publication summarizing the international experience in (2002), under the title "Measuring the NonObserved Economy”. It is worth to point out that in the "Guide ..." the experts emphasize those tasks that were not highlighted before this work, namely: the formation of a single, new optimal approach to shadow economy understanding; developing of the measures to reduce shadow, illegal activities, activities in the informal sector or the production of households for their own final consumption. It is primarily aimed at ensuring that production activities are "observed" as more as possible, or in order to collect sufficient data to be displayed in national accounts. Accordingly, by giving some insight into the causes and extent of shadow and illegal activities, "Guide ..." does not provide advice on shadowing reducing, since this is not a matter of statistics (Measuring the Non-Observed Economy, 2002). Also, a partial attention paid to tax evasion in this research is related only to the types of activities that fall within the scope of the production of the CHC-93. Tax evasion connected to the types of activities which are non-productive one and are not included in GDP is not being explored (On approval of Methodological provisions for calculating the volume of the economy that is not directly observed, and the Organizational Scheme for conducting and using the calculations of the economy, which is not directly observed, 2018).

It is worth noting that the necessity of taking into account the results of illegal activity (crimes in particular and offenses in general) during the formation of an assessment of the threat to the national economy is undoubtedly correct, since the unlawfulness as a sign of the phenomenon reflects its essence as a violation of the security state. However, it is not clear from the given definitions, which are formulated taking into account the content of the phenomenon of the "shadow economy", which elements should reflect its internal structure - income, indicators, actual economic activity, its material results or, in general, economic processes. In addition, it is impossible to establish a causal and consequential connection between the processes and results, in particular, the research needs a "plane" in which they are located. This is primarily connected with the characterization of the "result" as a category of statics, and the "processes" - to the dynamics.

Nowadays the scope and conditions for the implementation of certain types of activity that belong to the so-called "productive part" of the shadow economy have significantly changed. Actually, the objects are to be included to such "productive part" needs to be reviewed, especially in the theory. In case if previously, as an example, the results of households, tutoring, etc. were often presented, today, such an economic activity is regulated, and its results make up a significant part of the population's income.

Within the accounting and statistical approach, it is not possible to assess the extent, structure, and impact of illegal activities that are not related to the production of real GDP. The elements of the shadow economy, on the one hand, are all types of purely criminal and economic crimes, which extremely expands the limits of the shadow economy, and on the other hand, the system of national accounts, which is connected only with the analysis of production and consumption of GDP, which is often accompanied by the desire to reduce statistical errors in the process of calculations. There is also a category of economic offenses and crimes, for which under this methodology it is impossible to make a quantitative assessment, taking into account their specific impact on the economic system. The imperfection of the information base of statistical calculations is a significant problem. 
Official statistical indicators are based on the results of regular statistical observations, including information from the government agencies, in particular, controllers. In this case, it is worth noting the lack of a unified approach to the criteria and elements filling the relevant databases. In particular, this can easily be seen on the example of the State Fiscal Service of Ukraine, which is the central executive body that implements both the state tax policy and the policy in the field of state customs, etc. however, the approaches for the formation of statistical data by this entity in these areas are different since they remain unchanged from the time when there were separate central bodies that ensured the implementation of the respective policies of the state. The further development of tax and customs affairs is based on the creation and implementation of an electronic integrated system for tracking the movement of goods throughout the supply chain to different countries, continuous tax, customs and audit control from the border to the final buyer on the basis of a unified commodity description of goods, its introduction in the accounting, tax and customs accounting, which will be carried out electronically. The transition to a new level of governance allows creating a mechanism that will work more effectively to ensure Ukraine's national interests and security, will be the basis for counteracting the shadow economy.

Therefore, one of the important directions for increasing the effectiveness of counteraction the economic shadowing should be to improve the mechanism for the formation of reliable results from statistical observations. This will be facilitated by the unification of approaches to the criteria, components of filling the relevant databases of related controlling entities, verification of the information provided by them. The strategic importance of such proposals is actualized by the transition from the electronic society to the information, the possibility of ensuring the transparency of the activities of the higher mentioned entities to counteract the economic shadowing and the use of countermeasures not related to interference with the activities of the participants in the economic sphere.

In general, the accounting and statistical approach can be effectively used to identify the productive sectors of the shadow economy and assess its scale, for the formation of economic and legal policies. Although the scientists point out Varnalia Z.S. (2006) that it needs to be complemented by other approaches that are more capable of reproducing the redistributive nature of unlawful and socially harmful economic activity, it is worth noting that it produces a blurring of the limits of "state regulation of the economy" and "state counteraction to the shadow economy."

Some representatives of the economic science indicate: "shadow economy" is the economic term and it is not worth to be transferred to the legal ground. The "shadow" economy is, above all, an economic base for economic crime. It consists of three blocks: 1) the legal (unregulated by the state) production of goods and services; 2) violation within the limits of permitted economic activity (illegal manufacture of officially authorized goods and illegal provision of officially authorized services, tax evasion and other obligatory payments within the official economy, currency and financial and stock violations and fraud); 3 ) prohibited activities (criminal offense and corruption) (Turchynov, 1987). At the same time, the two most powerful blocks of the "shadow economy", identified by the author in this research, are, in essence, evidence of an economic crime, diluted by a very small extent of administrative offenses. And only one block is legal, unrelated to behaviour that violates the law since it exists within the limits of the authorized state activity.

It is worth noting that the author of the approach, which became the basis for characterizing primarily by the economists of illegal activities as an economic activity, is G.S. Becker. The scientist in the work "Crime and Punishment: An Economic Approach" has developed a new direction of research - the analysis of crimes as a type of activity, which subjects choose rationally, comparing the benefits and costs of probable arrest and punishment (Becker, 1968). This approach has become widespread, first of all, in defining the concept of "shadow economy", according to which, along with the types of economic activities that are carried out with violations, economic crimes, unregulated households, and their content includes crimes of a general criminal character. Also, it should be noted that the scientist was intended to investigate not the actual criminal activity as a part of the shadow economy, but the cost of committing a crime at particular stages and in general. An attempt to understand and determine the ratio of criminal activity and economic (legal) activity in connection with their sole purpose - the achievement of economic benefits is valuable. Characteristics are not exclusively economic activity, but activities in the field of economics, aimed at obtaining material benefits (result).

\section{The essence of economic shadowing as a process of forming a threat to national security in the economic sphere}

Due to the thorough development of the concept of "shadow economy", it seems methodologically to be correct formulating the concept of "economic shadowing", which will enable the reflection of the unity of these concepts, due to the fact that they characterize a single fact (phenomenon), at the same time, will contribute to the allocation of mandatory signs of the latter one as a threat and specification of the systemically forming element, object of counteraction in order to ensure economic security.

Separate individual attempts to define the term "shading" exist in foreign scholars, but their value is determined exclusively by the enrichment of scientific 
thought and often does not differ from the already established legal traditions, which only produce criticism of their views and do not allow marking their originality.

In a number of definitions, the concept of "shadow economic activity" forms the basis (defines the meaning) of the term "shadow economy", as well as, in fact, the concept of "shadowing". In view of the fact that the term "activity" means doing something in a certain way, "shadow economic activity" from a lexical point of view specifies the actual way of carrying out such activity in the corresponding sphere - the economy (Buzel, 2009). Accordingly, the adjective "shadow", obviously, means that the activity is carried out by concealing (analogue shadowing). The indicated duplication in the definition of two non-identical concepts requires a delineation of activities that will determine the architecture of the concepts. Since the concepts analysed are mediated primarily by statistical purposes - counting, then it is subject to both the results of activity and the number of facts of activity.

Nowadays it is difficult to determine the activity as latent because, again, there are two main approaches to the characterization of this feature: concealment as a "way of doing business" - hidden activities and concealment as a "result of activity" - activities of concealment. Within conceals: in one case, the activity and its results, in the other - only the results. However, when it comes to unregulated activities, it is hidden, but only in connection with the lack of a requirement for it in a particular way to conduct, "detect", record, etc. That, in fact, the subject makes it does not hide, but including it into the shadow economy, researchers seeking to identify the major sign of activity "hidden", describe the unregulated activities as well as "hidden". The difference in these approaches is obvious; therefore, understandable are problems in determining the means of influence aimed to "fade", "withdrawal from the shadow" activities, belonging to the shadow economy. Since it (these measures) cannot be complex, paying attention to these characteristics, they, are being only called the complex, but in fact are divided into at least two different groups, indicating that it is dependent on "the structural elements of the shadow economy."

Since this activity is considered to be illegal, some scientists consider "lawlessness", or rather, "illegality" of activities both in the case of its implementation outside the law, while summarizing, not separating the reasons: in one case - it is generally lack of regulation, in the other - violation of the legal regulations.

\section{Conclusions}

Based on the analysis of the approaches to research and the formulation of the concept and content of the "shadow economy", it should be noted that the characteristic of its own activities is the common denominator in disclosing the essence of the concept and the notion of "economic shading". However, the nature of such activities will be significantly different, since the formation of a "shadow" in the plane of the economy is a consequence of shading (shadowing), so the "shading activity" and "activity associated with the result of shading" are the objects of characteristics.

A common feature of the shadow economy and economy is a fact that they appear in the economic space as a result of their activity, in particular, today, in most branches of law, which deal with offenses and responsibility for their commitment, the focus is on the business activity. According to its volume, any results of the activity, limited by the sphere of management, are counted, in other words, the result of a manifestation of the social activity of a person within the economy (economic activity as its component). Due to the fact that activity and its results are interdependent, it is obvious that the shadow economy proportionally depends on the processes of shadowing and, therefore, it seems logical firstly to calculate, and then to detect. Detection of criminal activity is mediated by its own result (damage). The level of the shadow economy is directly mediated by the result of the active behaviour of the subject in the field of economics (whether it is possible to concretize according to the above example - management). However, when it (activity) does not meet the requirements set by legal norms, it will be characterized as shadow activity (the content of the process of shadowing). That is, the activity of a person, which is mediated by the sphere of management or receiving a material result, benefits, etc. in a prohibited way, will be a shadow economy. Only in this case, one can apply a complex approach to the research of the phenomenon of the shadow economy since the activity of a person is determined by the subject of studying sociology, economics, criminology and other legal science. At the same time, the processes of shadowing of the economy also need to be counted since, along with the total volume of the shadow economy, which is an indicator of normal social and economic development, the definition requires either the volume or, rather, the level of threat to national interests in the economy. The above stipulates the necessity of forming a system of counteraction to the shadow economy, which will consist primarily of the targeted formally determined influence of the relevant subjects by legal means on the object (persons) by protecting and defence of the rights and freedoms, etc., in particular, economic relations both from violations by other subjects of management, and from violations committed by the subjects of power authorities.

The formation of the concepts of "shadow economy" and "economic shading" in the interconnection is a logical stage of cognitive activity within both the economic and legal sciences. Only under this condition we are able to clarify with the system-forming categories and provide a consistent and mutually objectionable 
research, based on the achievements of predecessors, representatives of various sciences, and are able to withstand to criticism.

Shadow economy is a broad approach is an activity in the field of economics aimed at obtaining a material result that is not reflected in official statistics and is not included in GDP.
Economic shading is a complex process of formation and implementation of economic mechanisms that are carried out in violation of requirements established by legal norms aimed at obtaining a material result that is not reflected in GDP and, provided that the critical level is reached, poses a threat to economic security.

\section{References:}

Becker G.S. (1968) Crime and punishment: an economic approach. Journal of Political Economy. Vol. 76 . № 2. P. 169-217. (in English)

Buzel V.T. (2009) Velykyy tlumachnyy slovnyk suchasnoyi ukrayinskoyi movy [Great explanatory dictionary of modern Ukrainian language]. layout. and goal Ed. Irpen: Perun University. 1736 p. (in Ukrainian)

Economy. Retrieved from: https://uk.wikipedia.org/wiki/Economy. (accessed 10 May 2018).

Hermann H. Hoppe (1995) Economic science and the Austrian method. Retrieved from: https://mises.org/ library/economic-science-and-austrian-method (accessed 10 May 2018)

Kabmin pridumal, kak vytashchit biznes iz teni $i$ unichtozhit «nalogovyye yamy». [The Cabinet came up with how to get the business out of the shadows and destroy the "tax pits"] Retrieved, May, 2018, from: http://www.segodnya.ua/economics/business/kabmin-pridumal-kak-vytashchit-biznes-iz-teni-i-unichtozhitnalogovye-yamy-757683.html (in Russian)

Kochev V.A. (2010) Konstitutsiya, pravo, ekonomika. [Constitution, law, economics]. Bulletin of Voronezh State Economic University. Issue. 5. P. 45-49. (in Ukrainian)

Matzievsky N.S. (2010) Tenevaya ekonomika: analiz $i$ otsenki. [The shadow economy: analysis and evaluation]. Proceedings of Tomsk Polytechnic University. № 6. P. 22-29. (in Russian)

Measuring the Non-Observed Economy. (2002) Paris: A Handbook. P. 141.

Methodical recommendations for calculating the level of economic security of Ukraine: Order of the Ministry of Economic Development and Trade of Ukraine (dated October 29, 2013) № 1277. Retrieved from: http://www.me.gov.ua/Documents/List?lang=en-UA\&tag=MetodichniRekomendatsii (accessed 10 May 2018). Muntian V.I. (1999) Ekonomichna bezpeka Ukrayiny. [Economic security of Ukraine.]. Kyiv: KHIF Publishing House. (in Ukrainian)

North D. (2010) Ponimaniye protsessa ekonomicheskikh izmeneniy [Understanding the process of economic change]. Per. with English. K.A. Martynova, N.S. Edeliana. Moscow: ID Gos. University Higher School of Economics. 256 pp. (in Russian)

On approval of Methodical recommendations for calculating the level of the shadow economy: Order of the Ministry of Economy of Ukraine (dated February 18, 2009) No. 123 / Ministry of Economic Development and Trade of Ukraine. Retrieved from: http://www.me.gov.ua/LegislativeActs/Detail?lang=en-USA\&id=4bb297a0c900-404f-8c6f-5f76f18b1503 (accessed 10 May 2018)

On approval of the Methodological provisions for calculating the volume of the economy that is not directly observed, and the Organizational Scheme for conducting and using the calculations of the economy, which is not directly observed. (2018) Retrieved from: http://www.ukrstat.gov.ua/metod_polog/metod_doc/nr/nr_05.pdf; http://www.ukrstat.gov.ua/operativ/oper_new.html (accessed 10 May 2018).

On the Fundamentals of National Security of Ukraine: Law of Ukraine (dated June 19, 2003) No. 964-IV / The Verkhovna Rada of Ukraine. Information from the Verkhovna Rada of Ukraine. No. 39. Art. 351.

Popovych V.M. (2001) Ekonomiko-kryminolohichna teoriya detinizatsiyi ekonomiky: monohrafiya. [Economic and Criminological Theory of the Economists Deduction: Monograph]. Irpen: Academy of the State Tax Service of Ukraine. 524 p. (in Ukrainian)

Report on conducting a national risk assessment in the field of prevention and counteraction to the legalization (laundering) of proceeds from crime and terrorist financing. (2016) Kyiv. 204 p. Retrieved from: http://www.sdfm.gov.ua/content/file/Site_docs/2016/20161125/zvit_ukr.pdf. (accessed 10 May 2018).

Shemshuchenko Yu.S. (2002) Yurydychna entsyklopediya: $v 6 t$. [Law Encyclopedia: 6 t.]. Kyiv: "Ukr. Encyclopedia "by them. MP It is desirable. T. 6: T - Ya. 720 p.

Skakun O.F. (2013) Ekonomichna dominanta v pravoviy doktryni: teoretychnyy ekonomiko-pravovyy analiz. Pravova doktryna Ukrayiny: $v$ t. [Economic dominant in legal doctrine: theoretical economic and legal analysis. The legal doctrine of Ukraine: in 5 t.]. Per constituency. Ed. O.V. Petryshina, Yu.P. Bityak and others. Kharkiv: Law. T. 1: General theoretical and historical jurisprudence. Pp. 154-197. (in Ukrainian)

Tinovyy sektor $v$ Ukrayini: prychyny, obsyahy i naslidky: yak yoho suttyevo zmenshyty? [Shadow sector in Ukraine: causes, volumes and consequences: how to significantly reduce it?] Retrieved, May, 2018, from: http://www.kse.org.ua/uk/about/kse-news/?newsid=442 (in Ukrainian)

Tsishkovskiy Ye.A., Strelnikov K.A. (2007) Kategoriya «ekonomicheskaya bezopasnost»: semantika $i$ popytka konstruirovaniya zakonodatelnoy definitsii. Zakonodatelnaya definitsiya: logiko-gnoseologicheskiye, politikoyuridicheskiye, moralno-psikhologicheskiye i prakticheskiye problemy: materialy Mezhdunarodnogo «kruglogo stola» 
[The category of "economic security": semantics and an attempt to construct a legislative definition. Legislative definition: logico-gnoseological, political-legal, moral-psychological and practical problems: materials of the International Round Table] (Chernivtsi, September 21-23, 2006) (ed. V.M. Baranova, P.S. Patsurkivsky, G.O. Matyushkina). Nizhny Novgorod: Nizhny Novgorod INCT "Legal Engineering", p. 507-526.

Turchynov O.V. (1987) Tinova ekonomika (metodolohiya doslidzhennya ta mekhanizmy funktsionuvannya): [Shadow economy (research methodology and functioning mechanisms): author's abstract. Dis. doc. Econ. sciences]. (avtoref. dys. dokt. ekon. Nauk). Kyiv. 40 p.

Varnaliy Z.S. (2006) Tinova ekonomika: sutnist, osoblyvosti ta shlyakhy lehalizatsiyi [Shadow economy: the essence, features and ways of legalization]. Kyiv : NISS, 576 p. (in Ukrainian)

Varnaliy Z.S. (2009) Ekonomichna bezpeka: navch. posibnyk [Economic Security: Teaching manual]. Kyiv : Knowledge, 647 p. (in Ukrainain)

Varnaliy Z.S. (2015) Konkurentsiya i pidpryyemnytstvo: monohrafiya. [Competition and Entrepreneurship: Monograph]. Kyiv : Knowledge of Ukraine. 463 p. (in Ukrainian)

Varnaliy Z.S. (2017) Tinova ekonomika $v$ systemi instytutsionalnykh zahroz ekonomichniy bezpetsi Ukrayiny. Tinova ekonomika: svitovi tendentsiyi ta ukrayinski realiyi: materialy mizhvidomchoyi naukovo-praktychnoyi konferentsiyi [Shadow economy in the system of institutional threats to the economic security of Ukraine. Shadow economy: world trends and Ukrainian realities: materials of the interdepartmental scientific and practical conference] (Kiev, June 23, 2017) / red. V.V. Chernye, S.S. Chernyavsky, V.I. Shakun and others K.: National acad. inside cases, pp. 29-32. (in Ukrainian) 